\title{
REGIONAL TRANSFORMATION IN SEMARANG CITY, INDONESIA
}

\author{
Sri Rum GIYARSIH, Muh Aris MARFAI \\ Universitas Gadjah Mada, Yogyakarta, Indonesia
}

\begin{abstract}
Endowed with rapidly changing physical and socio-economic conditions, Semarang City in Central Java Province serves as an interesting case study of Indonesia's urban transformation. Secondary data, coupled with field observations and in-depth interviews with key informants and experts, were analyzed using both qualitative and quantitative descriptive methods to show complex variations in urban evolution between Semarang's numerous districts, with changes occurring much faster in some locations than in others. We show that urbanisation proceeds most rapidly where vacant open spaces and investment in various kinds of new public infrastructure are dominant, especially in such districts as Tembalang, Gunungpati, Genuk and Pedurungan. In contrast, transformation processes operate more slowly in Semarang's saturated inner core.
\end{abstract}

Key Words: urban transformation, region, Semarang city, Indonesia.

\section{Introduction}

In the last twenty years, several of Indonesia's cities have experienced rapid urbanization, with two contrasting impacts. Urbanisation attracts migrants to fulfill job opportunities, albeit paying from low to medium wages, while also increasing the numbers of the unemployed, creating slums or shanty towns, generating traffic congestion and many other classic urban problems (Giyarsih 2014). Such regional transformations have featured prominently in the recent analysis of Indonesia's regional development (Rahmawati 2015, Harini et al. 2016), and Giyarsih (2010) perceives them as a civilizing improvement. Despite this positive assessment, Tacoli (2003), Harini et al. (2014) and Novianty (2015) have identified various negative impacts resulting from the fast urbanisation in addition to those just mentioned. Obviously, there is the loss of agricultural land which is, according to Setyono et al. (2016), coupled with the infiltration of urban elements into the peri-urban space. However, Umar (2014), Woltjer (2014) and Anjarsariningtyas et al. (2016) also observe changes in many other social and economic dimensions. For example, wage systems have tended to replace mutual aid and, likewise, modern markets have largely replaced the traditional retail distribution.

Giyarsih (2014) provides three components of regional transformation, namely:

(a) An economic dimension, such as the change in occupational structures from agriculture to those in manufacturing, trade and services;

(b) Spatial dimensions, such as the conversion of agricultural land use to urban purposes and enhanced population mobility; and

(c) Such social dimensions as the shift from a complex set of traditional customs in the rural society to a simpler and more homogeneous set of behaviors in the urban space.

Yunus (2008) also confirms these dimensions and, in particular, he notes the distinctive rural (paguyuban) and urban (patembayan) behavior systems.

Like other metropolitan regions in Indonesia - including Jakarta, Bandung, Surabaya, Medan, Palembang, and Makassar - Semarang has experienced regional transformation (Wilonoyudho 2011). As the capital city of Central Java Province, it has witnessed the fastest development in 
the province. Administratively, the city comprises 16 districts and our research tracks the different patterns and processes of economic, social and urban transformation occurring across all of them, while assessing both their positive and negative consequences. In this task, we will also (a) refine theories about the growth processes involved; and (b) assess their implications for an improved urban management, focusing especially on city and infrastructure planning over both the short- and long-term, and also on environmental management. Thus, we blend theory and practice, enriching the field of urban geography, and helping various stake-holders to develop better analytical frameworks for managing the city and its surrounds.

\section{Methodology}

Semarang City in Central Java Province (Fig. 1) was selected as a research area because it has been changing rapidly, in both physical and socio-economic terms, either from rural to urban or from a less urban to a more urban area (Marfai and King 2008, Marfai et al. 2008). Its selection also reflects Semarang's dominant role in Central Java. Moreover, Wilonoyudho (2011) concludes that the city has experienced excessive urbanization, particularly due to an unbalanced relationship between the level of urbanization and economic growth. In short, Semarang is overcrowded with unproductive informal sectors, unlike urbanization in many developed countries which depend on an advanced industrial base.

As noted earlier, the information used in this research includes statistical data, augmented by field observations and in-depth interviews. The former were derived from Subdistrict in Figures for 9 districts in 1990 and 16 districts from 2000 onwards. Data for 2012 came from Semarang City in Figures provided by Indonesia's Statistics Agency (Biro Pusat Statistik - BPS). Additional data were provided by Semarang's Regional Development Planning Agency (BAPPEDA). Statistics were analyzed quantitatively using univariate procedures. In-depth interviews were held with key officials and other expert staff from (a) BAPPEDA and (b) the Department of Urban and Regional Planning within Universitas Diponegoro's Faculty of Engineering. All interviewees had deep knowledge or contemporary urbanisation processes in Semarang and elsewhere in Indonesia. Qualitative techniques were used to analyze the primary data obtained from formal interviews and discussions with several other informants.

Our research employed five key variables to estimate the extent of urban transformation in different districts in and around Semarang. These are: (a) population density; (b) population growth; (c) the percentage of farm households; (d) the percentage of built-up area; and (e) the availability of key socio-economic facilities. These were combined into a single index of ruralurban transformation, albeit complemented by field observation and in-depth interviews to enrich the understanding of the processes involved during the period between 1990 and 2012, including data for 2000. However, the level of regional transformation in 1990 was determined using four variables only, i.e. without considering the population growth because of data unavailability. The assessment of socio-economic infrastructure relied solely on educational and religious facilities due to the paucity of data relating to other dimensions. Each of the 5 variables for each of Semarang's districts was assigned a score ranging from 1 to 3 , with 1 reflecting low, 2 medium, and 3 high transformation. Consequently, each district obtained a transformation score (or summary index) ranging from 5 to 15 . We arbitrarily assigned indices of 5 to 8 as low, 9 to 11 as mid-range, and 12 to 15 as reflecting high transformation. Indices were also computed for each of the census years: 1990, 2000, and 2012 - permitting the assessment of the transformation dynamics over time. Since a high percentage of farm households was deemed a negative transformative indicator, the scores 3,2 , and 1 respectively reflect low, middle, and high levels of farming activity. Aggregate regional transformation indices for every district of Semarang City in 1990, 2000, and 2012 are presented in Table 1. 


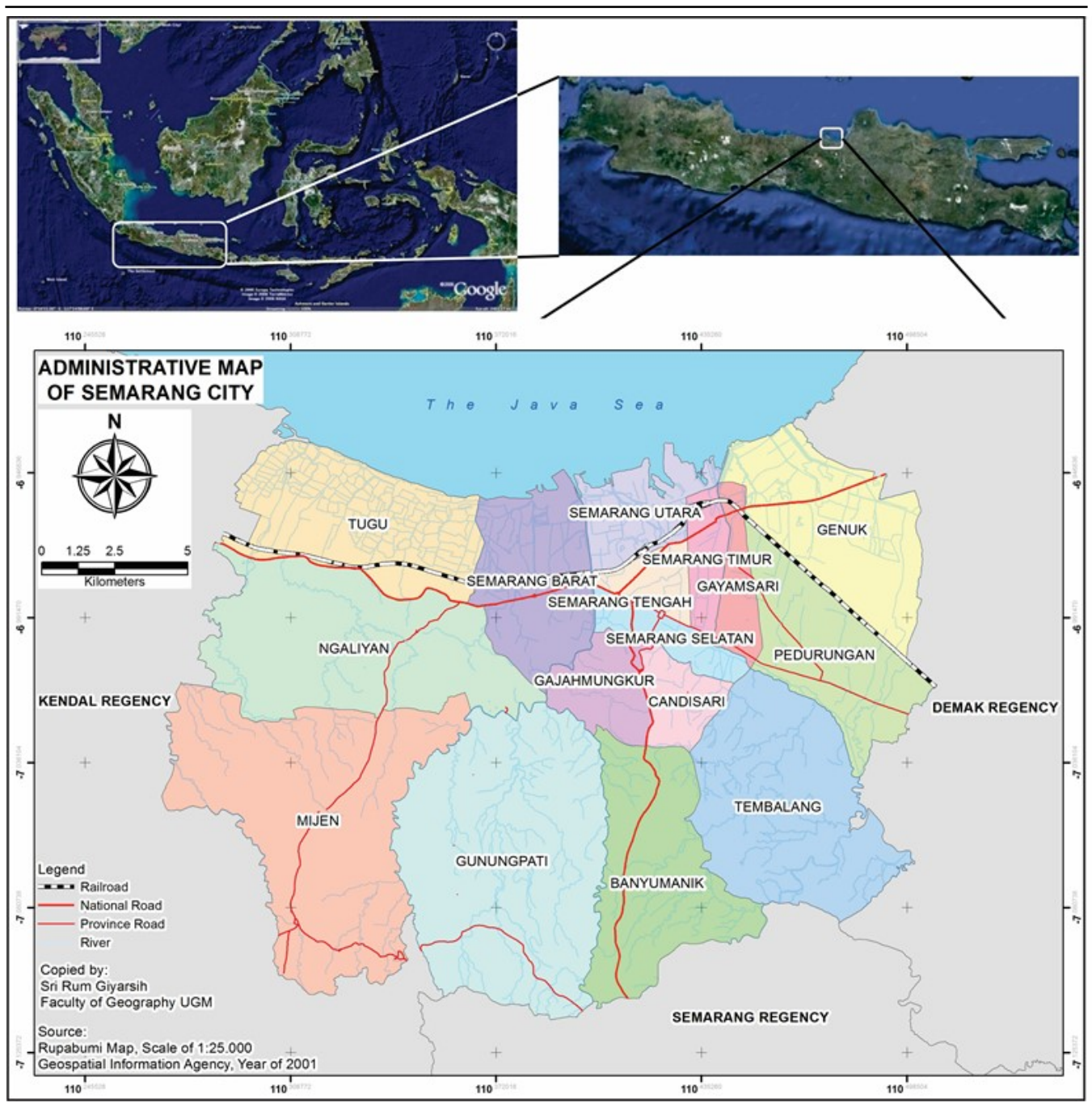

Fig. 1 - Administrative Map of Semarang City

\section{Results and Discussion}

In 1990, Semarang City consisted of 9 districts, five of which ranked of low to middle transformation. The remaining four districts exhibiting high transformative capacity enabled Semarang as a whole to attain mid-level regional transformation - or around $56 \%$ of the maximum possible. By 2000, Semarang administratively comprised 16 districts, reflecting the occurrence of urban sprawl over the previous decade. Indonesia's district and city configurations are set by the national government in Jakarta. And Government Regulation No. 50 in 1992 affirmed the expansion of Semarang City from 9 - set long in the past by Government Regulation No. 16 in 1976 - to 16 districts. The addition of seven additional districts to Semarang reflected an interesting philosophy that smaller areas enable more efficient regional management and development. Table 1 shows that 13 districts recorded high 
The regional transformation level in every district of Semarang city in the period 1990-2012

\begin{tabular}{|c|c|c|c|c|}
\hline \multirow{2}{*}{ No } & \multirow{2}{*}{ Districts } & \multicolumn{3}{|c|}{ Levels of Regional Transformation } \\
\hline & & 1990 & 2000 & 2012 \\
\hline 1 & Mijen & Low & Middle & High \\
\hline 2 & Gunungpati & Middle & Middle & High \\
\hline 3 & Banyumanik & No data & High & High \\
\hline 4 & Gajah Mungkur & No data & High & High \\
\hline 5 & South Semarang & High & High & High \\
\hline 6 & Candisari & No data & High & High \\
\hline 7 & Tembalang & No data & High & High \\
\hline 8 & Pedurungan & No data & High & High \\
\hline 9 & Genuk & Middle & High & High \\
\hline 10 & Gayamsari & No data & High & High \\
\hline 11 & East Semarang & High & High & High \\
\hline 12 & North Semarang & High & High & High \\
\hline 13 & Central Semarang & High & High & High \\
\hline 14 & West Semarang & High & High & High \\
\hline 15 & Tugu & Low & Middle & High \\
\hline 16 & Ngaliyan & No data & High & High \\
\hline 17 & Semarang City & Middle & High & High \\
\hline
\end{tabular}

Source: BPS Semarang City $(1990,2000,2012)$

transformation by 2000 , with only three being mid-range so that transformation was proceeding rapidly at roughly $81 \%$ of the maximum. And by 2012 , every district in the city recorded a highlevel regional transformation.

The districts that experienced a change in their levels of regional transformation within the period of 1990 and 2000 were Mijen, Tugu, and Genuk. The first two increased from low to middle by 2000 , while the level in Genuk District increased from middle to high. All are located peripherally to Semarang's CBD, as shown in Fig.1. Between 2000 and 2012, an increase in regional transformation level occurred in three districts with mid-level regional transformation in 2000, i.e. Mijen, Gunungpati, and Tugu. All three attained high-level regional transformation status by 2012 and they were again located towards Semarang's western fringe. Consequently, the regional transformation level of all Semarang's districts collectively in 2012 was high. Thus, in the 22 years from 1990 to 2012, Semarang City had experienced an upward change in its pace of regional transformation, i.e. from mid-level at the start of the period to a high-level from 2000 to 2012. Its urban characteristics changed over time, which was in line with the change occurring in the society.

Thus far, our analysis has focused on Semarang's past and present regional transformation. The city has experienced rapid population growth and economic development as a consequence of its strategic position in the North Coast Road and its functionality as both a regional and national transport node. According to Wilonoyudho (2011), the spontaneous urban agglomeration along regional transport routes in Semarang parallels changes in the structure of commercial activity and in turn its spatial organisation. One particularly important event was the shift in CBD urban functions from manufacturing to business and community services which led to the marginalization of the urban poor (Wilonoyudho 2011). Luxurious hotels and shopping 
malls in the city centre replaced the dwellings of indigenous peoples with low socio-economic status. These 'indigenous' people were not a separate ethnic group, but they were simlpy longterm residents in this district (i.e. the city center).

Manufacturing activities often require considerable space, which is increasingly difficult to find in Semarang's Central Business District (CBD). Thus, many manufacturing activities have chosen to locate on the city's outskirts in such locations as the Kendal, and Demak Regencies (Fig. 2). This phenomenon is consistent with the studies carried out by Woltjer (2014), Sriartha and Giyarsih (2015), Li et al. (2015), Buxton et al. (2016), Giyarsih and Fauzi (2016), Liu et al. (2016), and Sudrajat (2016), which conclude that the urban development on the outskirts is due to: (1) the presence of adequate transportation links; (2) proximity to the activity center (CBD); (3) people's increasing preference for 'low density residential lifestyles'; and (4) the need for large sites by many industries and services on the peri-urban frontier. The location shift of manufacturing activities to Semarang's outskirts meets the criteria identified by the authors just cited. Therefore, many people and urban functions, including the functions of manufacturing activities, choose to reside in and grow on the outskirts instead of at the center of Semarang.

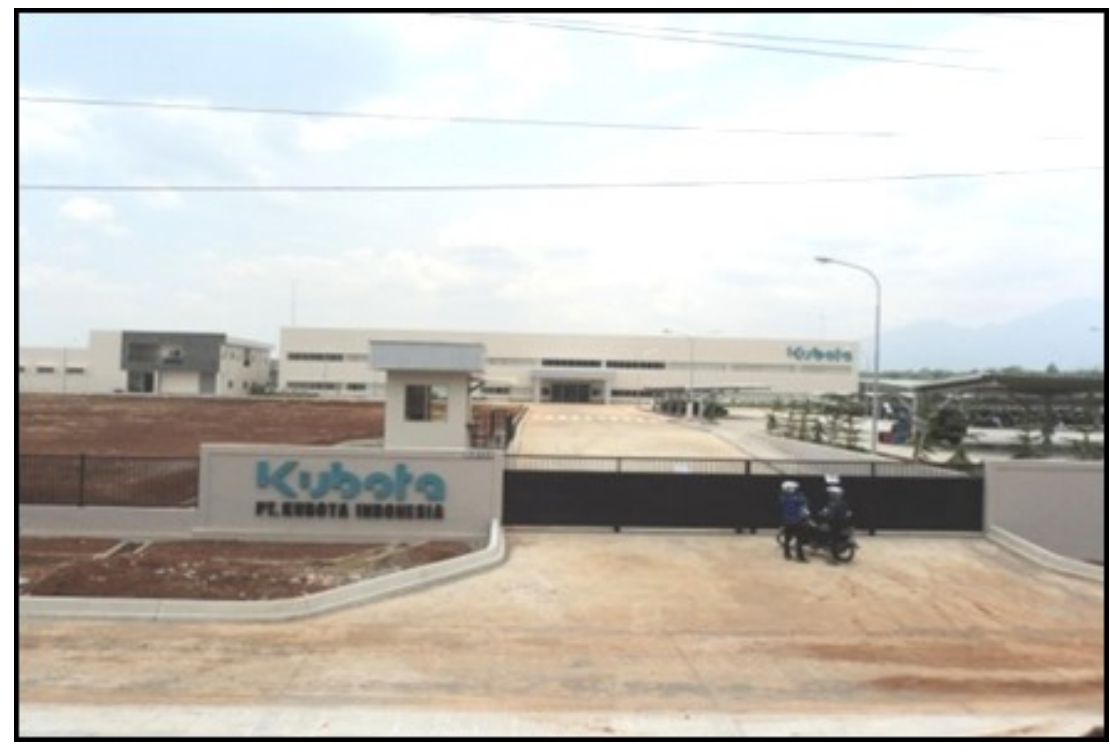

Fig. 2 - Industrial zone in Ngaliyan district adjacent to Kendal regency Source: Authors' Documentation (2016)

Wilonoyudho (2011) found that several old villages like Basahan, Jayenggaten, Morojayan, Petroos, Mijen, Sekayu, and others on Pandanaran Road at the center of Semarang City disappeared as they were converted to commercial and business use. This phenomenon indicates the land scarcity at the center of the city, which inevitably leads to the sprawl of urban people and functions to the outskirts. Due to the increasing population, several districts within Semarang City had initially increased their facilities and functions. Two of these districts are Mijen and Gunungpati. Based on the Statistics of Indonesia (BPS) for the Semarang City in 2012 , the population densities in Mijen and Gunungpati are of 878 people per $\mathrm{km}^{2}$ and 1,413 people per $\mathrm{km}^{2}$, respectively. These two districts have the lowest population density in the city. The results of field observation showed that the residential density in each district in Semarang 
City is parallel to the population density. An in-depth interview with Satya Hadi (Head of Physical Infrastructure Sector, the Regional Development Planning Agency of Semarang City) on May 22, 2016 corroborates the statistics. He confirmed the issue:

"In Semarang City, only two districts are still able to be developed. They are Mijen and Gunungpati Districts because their population densities are categorized as low. However, the development has to be conducted very carefully".

In the recent years, the Pedurungan, Genuk, and Tembalang Districts have experienced similar phenomena, namely the expansion of large-scale settlement carried out by developers. Pedurungan and Genuk became the destination of large-scale settlement expansion, driven by many residential property developers. One outcome was sharply rising - the commuter traffic to and from the city center and the rush hours are always associated with traffic jams (Fig. 3). Meanwhile, the urbanisation of Tembalang District was accelerated by the relocation of Universitas Diponegoro there.

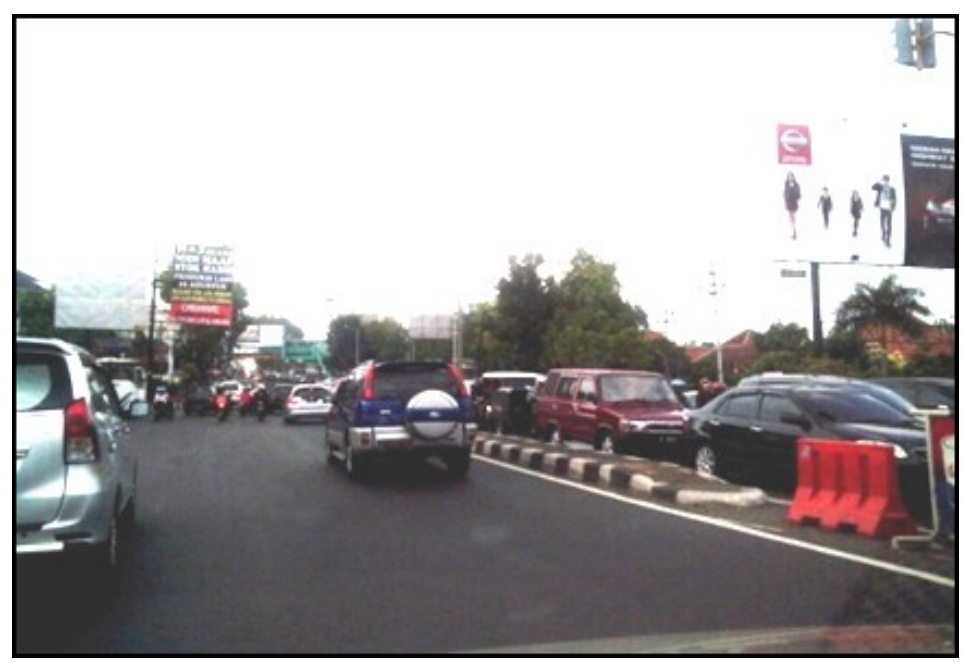

Fig. 3 - Rush-hour traffic from Demak regency Source: Authors' Documentation (2016)

The phenomena occurring in Pedurungan and Genuk Districts confirm the findings of Giyarsih and Fauzi (2016), who stated that residential property developers may play a pivotal role in regional transformation. Both small- and large-scale housing developments in these two districts triggered collateral development in the surrounding regions. This is because developers usually construct such supporting infrastructure as road networks, mobile phone towers, electricity lines, clean water pipes, sporting venues, and early education facilities such as kindergartens. Adjacent communities can usually tap into many of these supporting facilities and in turn become migrant destinations. Our findings are also in line with the work of Tuloli (2013) and Hatam (2016) who observed that one of the perceptible indicators of potential urbanisation is the drastic increase in land prices in latent settlement zones due to the influence of public facilities and utilities built by the construction developers elsewhere. Rising land prices also reflect the early infrastructure work by the property developers. The results of in-depth interview with Dr. Jawoto Sih Setyono, an expert on regional and urban planning from Universitas Diponegoro, on August 8, 2017, revealed that raw land prices are increasing by 
15\%-20\% annually, especially in those areas equipped with supporting infrastructure.

The Tembalang District experienced especially rapid urban transformation when, gradually between 1987 and 2012, the Universitas Diponegoro moved from Central Semarang to the area. Over 44000 students enrolled in the University had to access the area daily and dramatically increased urban traffic density. Unsurprisingly the move also increased the demand for student board and lodgings, food stalls, groceries, computer rental shops, photocopying and laundry services, internet cafes etc., all of which sought to support the university life (Fig. 4). During an in-depth interview, Dr. Jawoto Sih Setyono stated:

"In the past, in the beginning of the relocation of Universitas Diponegoro, the situation in Tembalang [District] was quiet. No socio-economic facilities supported university life. The condition of the traffic was not as heavy as today."

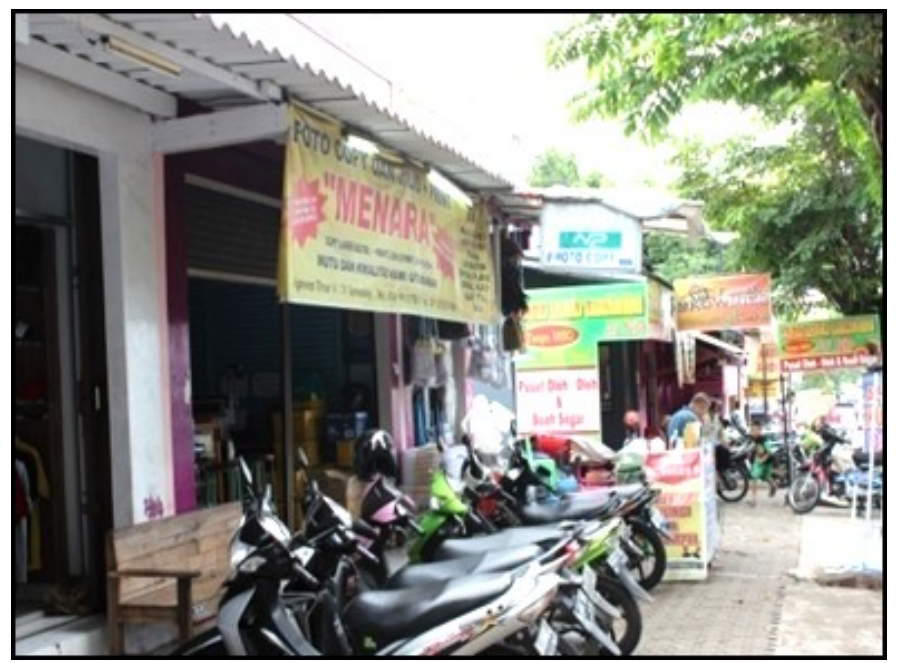

Fig. 4 - The emergence of socio-economic activities to support the university life of Universitas Diponegoro Source: Authors' Documentation (2016)

Our research findings corroborate Sriartha et al. (2015), who emphasize the role of public facilities as a trigger for regional transformation. In our case, the establishment of a university became a pull-factor for the urbanisation of Tembalang and adjacent locations. Table 2 shows the number of migrants in every district in Semarang City and that Pedurungan, Genuk, and Tembalang received the highest number of in-migrants in 2012. Indeed, in-migration in those locations exceeded the number of births. Therefore, according to the theory developed by Giyarsih and Alfana (2013), these three districts have become the destination of migrant influxes. The findings of Giyarsih and Fauzi (2016) and Ma'fudz (2016) also confirm this observation.

Rachmawati et al. (2004) found similar phenomena in the Sleman Regency's Ngaglik District a Special Region of Yogyakarta - after the establishment of the Universitas Islam Indonesia there. Similar phenomena were also found by Sarwadi et al. (2013) and Sriartha and Giyarsih (2015) in the Bantul Regency's Kasihan District, another Special Region of Yogyakarta, after the establishment of Universitas Muhammadiyah Yogyakarta. Aside from the Tembalang District, the Gunungpati District is also developing rapidly after the establishment of Universitas 
Negeri Semarang. Formerly located in the Gadjah Mungkur District, it also relocated gradually between 1989 and 1993 and, by 2012, it had 32037 students enrolled. Before this event, the receiving district was a quiet rural location with considerable agricultural land, but afterwards it was expected to show a similar trajectory to Tembalang after the arrival of the Universitas Diponegoro (BPS Kota Semarang 2012). Field observation also showed that the regional development in some areas in Semarang City was associated with the presence of a college campus, for example the areas close to the campus of Universitas Diponegoro. The research revealed that student numbers at the Universitas Diponegoro increased by $10 \%$ over the last ten years.

Table 2

The number of births, deaths, and in- and out-migration in Semarang City in 2012 (in people)

\begin{tabular}{|l|r|r|r|r|r|}
\hline Districts & Births & Deaths & In-migration & Out-migration & $\begin{array}{c}\text { Total } \\
\text { Change }\end{array}$ \\
\hline Mijen & 859 & 327 & 2115 & 982 & 1665 \\
\hline Gunungpati & 1095 & 384 & 1851 & 1011 & 1551 \\
\hline Banyumanik & 1794 & 736 & 3521 & 3967 & 612 \\
\hline Gajah Mungkur & 972 & 412 & 1394 & 1680 & 274 \\
\hline South Semarang & 1073 & 650 & 1481 & 2335 & -431 \\
\hline Candisari & 1261 & 621 & 1666 & 2224 & 82 \\
\hline Tembalang & 2505 & 892 & 5688 & 2900 & 4401 \\
\hline Pedurungan & 2550 & 936 & 5301 & 5245 & 1670 \\
\hline Genuk & 1717 & 424 & 3624 & 1740 & 3177 \\
\hline Gayamsari & 1266 & 434 & 2140 & 2421 & 551 \\
\hline East Semarang & 1065 & 666 & 1429 & 2546 & -718 \\
\hline North Semrang & 1939 & 1004 & 2397 & 3552 & -220 \\
\hline Central Semarang & 982 & 610 & 1254 & 2401 & -775 \\
\hline West Semarang & 2273 & 1122 & 3341 & 5644 & -1152 \\
\hline Tugu & 465 & 154 & 780 & 483 & 608 \\
\hline Ngaliyan & 1818 & 640 & 4199 & 2895 & 2482 \\
\hline Semarang City & 23634 & 10012 & 42181 & 42026 & 13777 \\
\hline
\end{tabular}

Source: BPS Kota Semarang (2012)

A rapidly growing region tends to become the destination of migrant influxes. In term of employment, regional transformation is characterized by the shift of the employment sector from Agriculture (A) to Manufacture (M) and then to Services (S). Table 3 presents the percentage of the population of Semarang City according to the employment sectors, and it shows that the agricultural sector in every district in Semarang City does not significantly contribute to population employment, except at Mijen. On the contrary, the services sector has the predominant role in absorbing workers in the research area. A conspicuous phenomenon occurs in the nonlinearity of the employment sector shift in the research area, which unlikely occurs in the employment transformation of developed countries.

The sectoral structure of Indonesia's workforce has evolved in a non-linear fashion from sector $A$ to $M$ and then to $S$. The nation lacks large-scale and/or highly capital intensive industries whose great efficiency forces workers to embrace the services sector, albeit often efficiently run and capital intensive. Indonesia's manufacturing industries tend to be small- and often household-scale enterprises, which absorb many workers. Indonesia's urban-based services 
sector is also dominated by informal working arrangements which are neither highly capital nor technology intensive, as in most developed countries. Thus, as Wilonoyudho (2011) observed, Indonesia's employment transformation moves non-linearly, with agricultural workers often moving directly to the services sector without embracing manufacturing.

Table 3

The Semarang's workforce employed in agriculture, manufacturing and services (2012)

\begin{tabular}{|l|r|r|r|}
\hline District & Agriculture \% & Manufacture \% & Services \% \\
\hline Mijen & 43 & 27 & 30 \\
\hline Gunungpati & 20 & 27 & 53 \\
\hline Banyumanik & 7 & 5 & 88 \\
\hline Gajah Mungkur & 0 & 13 & 87 \\
\hline South Semarang & 0 & 20 & 80 \\
\hline Candisari & 0 & 19 & 81 \\
\hline Tembalang & 2 & 1 & 96 \\
\hline Pedurungan & 3 & 28 & 69 \\
\hline Genuk & 21 & 40 & 39 \\
\hline Gayamsari & 1 & 51 & 49 \\
\hline East Semarang & 0 & 29 & 71 \\
\hline North Semarang & 0 & 25 & 75 \\
\hline Central Semarang & 0 & 20 & 80 \\
\hline West Semarang & 1 & 34 & 65 \\
\hline Tugu & 17 & 20 & 63 \\
\hline Ngaliyan & 14 & 27 & 59 \\
\hline Semarang & 7 & 26 & 67 \\
\hline
\end{tabular}

Source: BPS Kota Semarang (2012)

Workers in Semarang's predominantly informal services sector tend to have low education and skill levels (Sarjono 2005, Alisjahbana 2006, Wilonoyudho 2011) and, consequently, they receive low incomes. In order to earn money in the informal sectors, workers have to be willing to adapt quickly to the emerging demand and opportunity and they contribute to the relatively small financial capital.

\section{Conclusions}

Semarang has been experiencing a rapid regional transformation, although several districts close to the city center have reached a kind of saturation point. The lack of open space and developable land are restricting opportunities for further development. In turn, this encourages the spread of industries, services and employment to more peripheral locations able to absorb many different urban functions flexibly and adaptably, transforming themselves in the process. For example, the Tembalang and Gunungpati Districts received many sprawling urban functions following the establishment of Universitas Diponegoro and Universitas Negeri Semarang respectively, growing rapidly in their wake. Following a different route, the Genuk and Pedurungan Districts benefitted from property developers engaged in large-scale residential subdivision and the provision of considerable economic and social infrastructure, which also stimulated regional development significantly. The urban function shift to the districts located on the outskirts of Semarang make them the destination of migrant influxes. Thus the city's development is dynamic, multi-faceted, and accelerating in often complex and unforeseen ways. 


\section{Acknowledgements}

Authors would like to express their gratitude to the Graduate School of UGM for providing research funding through the scheme of Competitive Lecturer Research Grant SPs in 2015. Authors would also like to thank Prof. Ir. Suryo Purwono, MA., Ph.D. and Prof. Dr. Ir. Sunarru Samsi Hariyadi, M.Sc., for their significant inputs in improving this article. This gratitude also extends to Popy Haryani and Dewi Nursetyasari for their assistance in data collection.

\section{References}

ALISJAHBANA (2006), Marginalisasi Sektor Informal Perkotaan, ITS Press, Surabaya.

ANJARSARININGTYAS R., LAKSMIASRI W., PRATIWI A. A., DAN GIYARSIH S. R. (2016), Food Security in Urban Sprawl Effected Area: Case Study in Sub Districts on The Outskirts of Yogyakarta City, Proceeding of The $13^{\text {th }}$ International Asian Urbanization Conference, 104-114.

BPS KOTA SEMARANG (1990), Kota Semarang Dalam Angka Tahun 1990, BPS Kota Semarang, Semarang.

BPS KOTA SEMARANG (2000), Kota Semarang Dalam Angka Tahun 2000, BPS Kota Semarang, Semarang.

BPS KOTA SEMARANG (2012), Kota Semarang Dalam Angka Tahun 2012, BPS Kota Semarang, Semarang.

BUXTON M., CAREY R., PHELAN K. (2016), The Role of Peri-Urban Land Use Planning in Resilient Urban Agriculture: A Case Study of Melbourne, Australia, Balanced Urban Development: Options and Strategies for Liveable Cities 72, 153-170.

GIYARSIH S. R. (2010), Urban sprawl of the city of Yogyakarta, special reference to the stage of spatial transformation, Indonesian Journal of Geography 42 (1), 47-58.

GIYARSIH S. R., ALFANA M. A. F. (2013), The Role of Urban Area as The Determinant Factor of Population Growth, Indonesian Journal of Geography 45 (1), 38-47.

GIYARSIH S. R. (2014), The role of Yogyakarta and Surakarta cities in the intensity of the regional transformation of two villages located in the Yogyakarta-Surakarta corridor, Romanian Review of Regional Studies 10 (1), 15-22.

GIYARSIH S. R., FAUZI N. (2016), Factors That Affect Urban Sprawl Symptoms in Sub Urban Areas of Yogyakarta, Proceeding of The $8^{\text {th }}$ International Graduate Students and Scholars' Conference in Indonesia, 314-329.

HARINI R., GIYARSIH S. R., ARIANI R. D., DARUSASI R. (2014), Community Adaptation Model of Food Security Due to Global Warming in Kulon Progo, Proceeding of The $6^{\text {th }}$ International Graduate Students and Scholars Conference in Indonesia, 305-320.

HARINI R., NURJANI E., ARIANI R. D. (2016), The Impact of Climate Change on The Agricultural Sector in The Urban Fringe Area, Proceeding of The $13^{\text {th }}$ International Asian Urbanization Conference, 749-753.

HATAM R. (2016), Perkembangan Kota Kotamobagu, Universitas Gadjah Mada,

Faculty of Geography, dissertation manuscript, Indonesia.

LI Y., LI Y., WESTLUND H., LIU Y. (2015), Urban-rural transformation in relation to cultivated land conversion in China: Implications for optimizing land use and balanced regional development, Land Use Policy 47, 218-224.

LIU J., LIU Y., YAN M. (2016), Spatial and temporal change in urban-rural land use transformation at village scale-A case study of Xuanhua district, North China, Journal of Rural Studies 47 (Part B), 425-434.

MARFAI M. A., KING L. (2008), Potential vulnerability implications of coastal inundation due to sea level rise for the coastal zone of Semarang City, Indonesia, Environmental Geology 54 (6), 1235-1245.

MARFAI M. A., KING L., SARTOHADI J., SUDRAJAT S., BUDIANI S. R., YULIANTO F. (2008), The impact of tidal flooding on a coastal community in Semarang, Indonesia, The Environmentalist 28 (3), 237-248. 
MA'FUDZ A. A. (2016), Sebaran Keruangan Tipologi Wilayah Peri Urban di Kabupaten Sleman, Universitas Gadjah Mada, Faculty of Geography, thesis manuscript, Indonesia. NOVIANTY E. (2015), Balancing Local Government Capacity For A Sustainable PeriUrban Development: The Case of Karawang Regency, Journal of Regional and City Planning 26 (2), 71-85.

RACHMAWATI R., RIJANTA R., SUBANU L. P. (2004), Peranan Kampus Sebagai Pemicu Urbanisasi Spasial di Pinggiran Kota Yogyakarta, Indonesia Geographic Magazine 18 (1), 45-56.

RAHMAWATI Y. D. (2015), Self-Organization, Urban Transformation, and Spatial Planning in Greater Jakarta, Indonesia, Journal of Regional and City Planning 26 (3), 147-165. SARJONO Y. (2005), Pergulatan Pedagang Kaki Lima di Perkotaan: Pendekatan Kualitatif, Muhammadiyah University Press, Sukoharjo.

SARWADI A., GIYARSIH S. R., PRAMONO R. W. D. (2013), Penguatan Kapabilitas Masyarakat Pinggiran Kota, Studi Kasus Kecamatan Kasihan, Kabupaten Bantul Daerah Istimewa Yogyakarta, Universitas Gadjah Mada, Indonesia.

SETYONO J. S., YUNUS H. S., GIYARSIH S. R. (2016), The spatial pattern of urbanization and small cities development in Central Java: A Case Study of SemarangYogyakarta-Surakarta Region, Journal of Geomatics and Planning 3 (1), 53-66.

SRIARTHA I. P., GIYARSIH S. R. (2015), Spatial Zonation Model of Local Irrigation System Sustainability (A Case of Subak System in Bali), Indonesian Journal of Geography 47 (2), 142-150.

SRIARTHA I. P., SURATMAN S., GIYARSIH S. R. (2015), The Effect of Regional Development on the Sustainability of Local Irrigation System (A Case of Subak System in Badung Regency, Bali Province), Forum Geografi 29 (1), 31-40. SUDARAJAT S. (2016), Farmers Commitment in Maintaining Wetted Land Ownership Status in Peri-Urban Area of Yogyakarta, Indonesian Journal of Geography 48 (1), 91-101. TACOLI C. (2003), The links between urban and rural development, Environment and Urbanization Journal 15 (1), 3-12.

TULOLI Y. (2013), Perspektif Spasio Temporal Perkembangan Kota Gorontalo, Universitas Gadjah Mada, Faculty of Geography, dissertation manuscript, Indonesia.

UMAR F. (2014), Pengaruh Perkembangan Fisik Kota Terhadap Perubahan Lingkungan Fisikal dan Sosial Ekonomi di Wilayah Peri Urban Kota Makasar, Universitas Gadjah Mada, Faculty of Geography, thesis manuscript, Indonesia.

WILONOYUDHO S. (2011), Determinan dan Dampak Urbanisasi Berlebih di Kota Semarang, Universitas Gadjah Mada, Faculty of Geography, dissertation manuscript, Indonesia.

WOLTJER J. (2014), A global review on peri-urban development and planning, Journal of Regional and City Planning 25 (1), 1-16.

YUNUS H. S. (2008), Dinamika Wilayah Peri-Urban: Determinan Masa Depan Kota,

Pustaka Pelajar, Yogyakarta.

Initial submission: 21.05.2017

Revised submission: 02.10.2017

Final acceptance: 07.11.2017

Correspondence: Faculty of Geography, Universitas Gadjah Mada, Skip Utara Jln Kaliurang Bulaksumur, 55281 Yogyakarta, Indonesia.

Email: arismarfai@ugm.ac.id 
